\title{
The effect of synthetic pesticides and sulfur used in conventional and organically grown strawberry and soybean on Neozygites floridana, a natural enemy of spider mites
}

\author{
Thiago Castro, ${ }^{\text {a Samuel Roggia, }}$, b Vitalis W Wekesa, ${ }^{c, d}$ \\ Rafael de Andrade Moral, ${ }^{\mathrm{e}}$ Clarice GB Demétrio, ${ }^{\mathrm{e}}$ Italo Delalibera Jr ${ }^{\mathrm{a}}$ and \\ Ingeborg Klingen ${ }^{*}$
}

\begin{abstract}
BACKGROUND: The beneficial fungus Neozygites floridana kills the two-spotted spider mite Tetranychus urticae, which is a serious polyphagous plant pest worldwide. Outbreaks of spider mites in strawberry and soybean have been associated with pesticide applications. Pesticides may affect $N$. floridana and consequently the natural control of $T$. urticae. $N$. floridana is a fungus difficult to grow in artificial media, and for this reason, very few studies have been conducted with this fungus, especially regarding the impact of pesticides. The aim of this study was to conduct a laboratory experiment to evaluate the effect of pesticides used in strawberry and soybean crops on $\mathbf{N}$. floridana.

RESULTS: Among the pesticides used in strawberry, the fungicides sulfur and cyprodinil + fludioxonil completely inhibited both the sporulation and conidial germination of $N$. floridana. The fungicide fluazinam affected $N$. floridana drastically. The application of the fungicide tebuconazole and the insecticides fenpropathrin and abamectin resulted in a less pronounced negative effect on $\mathbf{N}$. floridana. Except for epoxiconazole and cyproconazole, all tested fungicides used in soybean resulted in a complete inhibition of $\mathbf{N}$. floridana. Among the three insecticides used in soybean, lambda-cyhalothrin and deltamethrin resulted in a significant inhibition of $N$. floridana.

CONCLUSION: The insecticides/ acaricides abamectin and lambda-cyhalothrin at half concentrations and fenpropathrin and permethrin and the fungicide tebuconazole at the recommended concentrations resulted in the lowest impact on $\mathbf{N}$. floridana. The fungicides with the active ingredients sulfur, cyprodinil + fludioxonil, azoxystrobin, azoxystrobin + cyproconazole, trifloxystrobin + tebuconazole and pyraclostrobin + epoxiconazole negatively affected $\mathbf{N}$. floridana.

(c) 2015 Society of Chemical Industry
\end{abstract}

Keywords: non-target effects; conservation biological control; integrated pest management; Tetranychus urticae; organic farming

\section{INTRODUCTION}

The two-spotted spider mite, Tetranychus urticae Koch (Acari: Tetranychidae), has a broad host plant range and is an important pest of many crops globally, including strawberries and soybeans. ${ }^{1-3}$ T. urticae lowers crop yields by feeding on mesophyll and parenchyma cells, which results in a reduction in photosynthesis and transpiration. ${ }^{4,5}$ Densities higher than five T. urticae per leaflet significantly reduce fruit production. ${ }^{6}$

Pesticides are frequently used to control pests and plant pathogenic fungi in strawberry and soybean crops. Acaricides are the main strategy used to control T. urticae in field crops; however, the pesticide application rate is often higher than the recommended rate, and pest population levels often peak after pesticide treatments. Some authors have suggested that increases in T. urticae populations after pesticide treatment are caused by the reduction in natural predators. ${ }^{7-9}$ Klingen and Westrum $^{10}$ also report that the reduction in the fungal pathogen Neozygites
* Correspondence to: I Klingen, NIBIO Norwegian Institute of Bioeconomy, Biotechnology and Plant Health Division, P.O. Box 115, NO-1431 Ås, Norway. E-mail:ingeborg.klingen@nibio.no

a Department of Entomology and Acarology, ESALQ - University of São Paulo, Piracicaba, SP, Brazil

b The Brazilian Agricultural Research Corporation - Embrapa Soybean, Londrina, Paraná, Brasil

C NIBIO Norwegian Institute of Bioeconomy, Biotechnology and Plant Health Division, Ås, Norway

d Department of Applied and Technical Biology, Technical University of Kenya, Nairobi, Kenya

e Department of Exact Sciences, ESALQ - University of São Paulo, Piracicaba, SP, Brazil 
floridana (Weiser and Muma) Remaudière and S. Keller (Neozygitomycetes: Neozygitales: Neozygitaceae) is associated with an increase in T. urticae populations. In Brazil, the spider mites T. urticae and Mononychellus planki became important pests in soybean after the introduction of soybean rust disease and as a result of the extensive use of fungicides in this crop. ${ }^{11}$

$N$. floridana has been observed infecting several species of Tetranychidae mites in various agroecosystems. ${ }^{12}$ The genus Neozygites has a restricted host range $\mathrm{e}^{13-15}$ and consists of only obligate pathogens that are difficult to maintain in artificial culture media. ${ }^{16} \mathrm{~N}$. floridana is reported to be a major factor causing a decline in populations of $T$. urticae in corn, cotton, peanut and strawberry crops, and infection levels as high as $80-100 \%$ have been reported. ${ }^{17-20}$ Conservation biological control by preservation of naturally occurring $N$. floridana, along with the judicious use of pesticides, as defined by Eilenberg et al., ${ }^{21}$ is a promising strategy to manage $T$. urticae.

$N$. floridana develops inside T. urticae as hyphal bodies, kills its host, penetrates the cuticle and produces primary conidia on conidiophores on the exterior of T. urticae. Primary conidia are actively ejected from the swollen brown cadavers, referred to as mummified mites. These conidia germinate to form the infective and more persistent capilliconidia that infect other mites. ${ }^{22}$

Only a few controlled laboratory studies have been conducted on the effect of pesticides to $N$. floridana as a natural enemy of T. urticae. $^{10,23}$ Some field or semi field studies have been conducted with $T$. urticae, however, ${ }^{20,24}$ and a few with another host species, T. evansi. ${ }^{25,26}$ In this study, we tested sulfur-based pesticides in addition to many other synthetic pesticides. To our knowledge, sulfur have until now not been tested against insect- and mite pathogenic fungi of the Neozygitales. According to Jepsen et al., ${ }^{27}$ sulfur is commonly used by grape growers against plant pathogenic fungi both in organic and conventional crop systems because it is effective and inexpensive, and resistance to sulfur by plant pathogenic fungi is not/seldom reported. Furthermore, sulfur is reported to have acaricidal and insecticidal effects, ${ }^{28}$ and there is evidence that it may have a negative impact on the fecundity and longevity of $T$. urticae. ${ }^{29}$ Nevertheless, sulfur applications are commonly associated with outbreaks of spider mites, apparently because sulfur is deleterious to predatory mites. ${ }^{30}$ Another possible explanation is that sulfur is detrimental to N. floridana.

Integrated pest management (IPM) is a practice that has been increasingly adopted in various agroecosystems to reduce the use of pesticides, avoid problems such as pest resurgence, resistance evolution and public concern about the negative effects of chemical pesticides on human health and the environment. ${ }^{31,32}$ In IPM, natural enemies are one of the tools used for alternative pest control. However, synthetic pesticides are still needed and used in IPM strategies, and it is important to seek the use of pesticides that are efficient against pests but selective to natural enemies. $^{33}$

The purpose of this study was to evaluate the effect of synthetic fungicides, acaricides and insecticides commonly used in strawberry and soybean in Brazil and in strawberry crops in Norway on the production of primary conidia and capilliconidia by the beneficial fungus $N$. floridana. Further, we tested the effect of sulfur-based pesticides, which are widely used against plant pathogenic fungi in both conventional and organic farms. Soybean pesticides used in Brazil were also included owing to the recent outbreaks of spider mites in this crop, most likely associated with the extensive use of fungicides against the soybean rust detected in this country in 2001.

\section{MATERIALS AND METHODS}

In order to test the effect of several pesticides on the $N$. floridana isolate ESALQ1420, two experiments were performed. In the first experiment, 12 pesticides (two acaricides, nine fungicides and one insecticide) that are commonly used to control pests and diseases in strawberry crops in Brazil and/or Norway were tested. In the second experiment, nine pesticides (three insecticides and six fungicides) used in soybean crops in Brazil were tested (Table 1). The pesticides were applied at two concentrations: (1) the recommended concentration on the product label (RC); (2) half of this concentration $(\mathrm{RC} / 2)$, to mimic field dilution factors (moisture/dew point). The pesticides were diluted in distilled water with $0.05 \%$ Tween 80 . Additionally, distilled water plus $0.05 \%$ Tween 80 was used as the control treatment, giving a total of 25 treatments for the first experiment and 19 for the second experiment. The first experiment was repeated three times, using a randomised complete block design with occasion as a complete block containing 25 treatments, and as a plot a petri dish with five mummified mites. The second experiment was a completely randomised experiment with 19 treatments and five replicates, and as a plot a petri dish with one mummified mite.

The N. floridana isolate ESALQ1420 was collected in Piracicaba, São Paulo, Brazil ( $\left.22^{\circ} 42^{\prime} 30^{\prime \prime} \mathrm{S}, 47^{\circ} 38^{\prime} 00^{\prime \prime} \mathrm{W}\right)$, from $T$. urticae on jack bean, Canavalia ensiformis (Fabales: Fabaceae). The mummified mites were placed individually on photoetched cover slips $(18 \times 18 \mathrm{~mm})$ with alphanumeric coded squares (Electron Microscopy Sciences, Hatfield, PA), which were placed on a $9 \mathrm{~cm}$ filter paper lining the petri dish.

For the pesticides used in strawberry, a computer-controlled sprayer (Bukard Manufacturing Co. Ltd, Rickmansworth, Herts, UK) was used for pesticide application, and pesticides were applied at a rate of $2.6 \mathrm{mg} \mathrm{cm}^{-2}$ at a pressure of 0.5 psi. For the soybean pesticides, a Potter spray tower (Burkard Manufacturing Co. Ltd) was used. The device was adjusted to a pressure of $0.7 \mathrm{psi}$, with an average of $1.5 \mathrm{mg} \mathrm{cm}^{-2}$. To avoid contamination between pesticide treatments, the sprayers were washed 3 times with water, alcohol, acetone and distilled water, and the first spray of each treatment was discarded. To obtain an RH suitable for N. floridana production of primary conidia (sporulation) and capilliconidia (germination), the sprayed mummified cadavers on sprayed coverslips were placed inside closed plastic boxes $(17.5 \times 11.0 \times 4.0 \mathrm{~cm})$ containing filter paper moistened with distilled water. The boxes containing the different treatments were wrapped in aluminium foil for darkness and put into climatic chambers at $25 \pm 2{ }^{\circ} \mathrm{C}$ and $100 \% \mathrm{RH}$ for $12 \mathrm{~h}$ in total darkness.

In order to determine the effect of pesticides on the sporulation and germination of $N$. floridana, coverslips were observed under a microscope $(400 \times)$, and the numbers of primary conidia and capilliconidia produced by the mummified cadavers were counted. Germinated primary conidia were defined as capilliconidia. The response variables used were total counts and total proportion of germination of the five mummified cadavers in the first experiment.

\subsection{Data analysis}

Quasi-Poisson models were fitted to sporulation (the production of primary conidia) data with the effect of block and treatment for tests with strawberry pesticides (first experiment) and the effect of treatment as the linear predictor for soybean pesticides (second experiment). Quasi-binomial models were fitted to the proportion of capilliconidial data with the same linear 
Table 1. Specifications of the pesticides (commonly used in strawberry and soybean) applied in the bioassays to determine the effect of pesticides on the production of primary conidia (sporulation) and capilliconidia (germination) of N. floridana

\begin{tabular}{|c|c|c|c|}
\hline Active ingredient & Trade name (manufacturer) & Type of pesticide (chemical group) ${ }^{a}$ & $\begin{array}{c}\text { Recommended } \\
\text { concentration }{ }^{c} \text { per } 100 \mathrm{~L}\end{array}$ \\
\hline Abamectin $^{a}$ & Vertimec $18 \mathrm{EC}$ (Syngenta) & Acaricide/insecticide/nematicide (avermectin) & $75 \mathrm{~mL}$ \\
\hline Azoxystrobin ${ }^{a}$ & Amistar 250 CS (Syngenta) & Fungicide (strobylurin) & $13 \mathrm{~g}$ \\
\hline Azoxystrobin ${ }^{\mathrm{b}}$ & Priori CS (Syngenta) & Fungicide (strobylurin) & $200 \mathrm{~mL}$ \\
\hline Azoxystrobin + cyproconazole ${ }^{b}$ & Priori Xtra CS (Syngenta) & Fungicide (strobylurin + triazol) & $200 \mathrm{~mL}$ \\
\hline Cyproconazole ${ }^{\mathrm{b}}$ & Alto 100 CS (Syngenta) & Fungicide (triazol) & $200 \mathrm{~mL}$ \\
\hline Cyprodinil + fludioxonil ${ }^{a}$ & Switch 62.5 WG (Syngenta) & Fungicide (anilinopyramidine + phenylpyrrole) & $50 \mathrm{~g}$ \\
\hline Deltamethrin ${ }^{b}$ & Decis EC (Bayer) & Insecticide (pyrethroid) & $200 \mathrm{~mL}$ \\
\hline Epoxiconazole ${ }^{b}$ & Opus CS (BASF) & Fungicide (triazol) & $400 \mathrm{~mL}$ \\
\hline Fenpropatrin ${ }^{a}$ & Danimen 300 EC (Sumimoto) & Insecticide/acaricide (pyrethroid) & $65 \mathrm{~mL}$ \\
\hline Fluazinam $^{\mathrm{a}}$ & Shirlan CS (Syngenta) & Fungicide (dinitroanaline) & $100 \mathrm{~mL}$ \\
\hline Iprodione ${ }^{\mathrm{a}}$ & Rovral 75 WG (Bayer) & Fungicide (dicarboximid) & $150 \mathrm{~g}$ \\
\hline Lambda-cyhalothrin $^{\text {b }}$ & Karate Zeon 50 CS (Syngenta) & Insecticide (pyrethroid) & $50 \mathrm{~mL}$ \\
\hline Penconazole ${ }^{a}$ & Topas 100 EC (Syngenta) & Fungicide (triazol) & $25 \mathrm{~mL}$ \\
\hline Permethrin ${ }^{b}$ & Talcord 250 EC (BASF) & Insecticide (pyrethroid) & $80 \mathrm{~mL}$ \\
\hline Procymidone $^{a}$ & Sumilex 500 WP (Sumimoto) & Fungicide (dicarboximid) & $100 \mathrm{~g}$ \\
\hline Propargite ${ }^{\mathrm{a}}$ & Omite 720 EC (Chemtura) & Acaricide (alkylchloride sulfite) & $30 \mathrm{~mL}$ \\
\hline Pyraclostrobin + epoxiconazole & Opera EC (BASF) & Fungicide (carbamate + triazol) & $400 \mathrm{~mL}$ \\
\hline Sulfur ${ }^{\mathrm{a}}$ & Thiovit Jet WG (Syngenta) & Fungicide (inorganic) & $300 \mathrm{~g}$ \\
\hline Sulfura & Kumulus WG (BASF) & Fungicide (inorganic) & $300 \mathrm{~g}$ \\
\hline Tebuconazole ${ }^{a}$ & Folicur 200 EC (Bayer) & Fungicide (triazol) & $75 \mathrm{~mL}$ \\
\hline Trifloxystrobin + tebuconazole ${ }^{b}$ & Nativo CS (Bayer) & Fungicide (strobylurin + triazol) & $333 \mathrm{~mL}$ \\
\hline
\end{tabular}

predictor. ${ }^{34}$ The quasi-likelihood approach was used because the data presented overdispersion, and hence $F$-tests were performed to assess significance of effects. Goodness of fit was assessed using half-normal plots with simulated envelopes. ${ }^{35}$ Treatment differences were tested using $95 \%$ confidence intervals. All analyses were performed using the $R$ statistical software environment ( $R$ Foundation for Statistical Computing, Vienna, Austria). ${ }^{36}$

\section{RESULTS}

\subsection{Effect of pesticides used in strawberry on N. floridana sporulation and germination}

Among the strawberry pesticides tested, the fungicides sulfur (Kumulus WG) and cyprodinil + fludioxonil completely inhibited the sporulation of $N$. floridana, even at half concentration $(\mathrm{RC} / 2)$ (Table 2). The fungicide fluazinam also reduced sporulation drastically at half concentration and completely inhibited sporulation at the recommended concentration (RC). Neither the fungicide tebuconazole and the insecticide/acaricide fenpropathrin at both concentrations nor the insecticide/acaricide abamectin at half concentrations significantly affected $N$. floridana sporulation. However, at the recommended concentration, abamectin showed a significant and drastic reduction in the production of primary conidia compared with the control.

All the strawberry pesticides tested affected germination (production of capilliconidia) significantly compared with the control at both concentrations; only tebuconazole at $\mathrm{RC} / 2$ showed no difference. The fungicides that resulted in no sporulation (the sulfur product Kumulus WG and cyprodinil + fludioxonil) did not result in any germination (production of capilliconidia). Further, the fungicides fluazinam, iprodione and the sulfur product Thiovit Jet WG and the acaricide propargite at both concentrations resulted in no or almost no germination. Both concentrations of the fungicides penconazole, azoxystrobin and procymidone also affected the formation of capilliconidia significantly. Tebuconazole at the recommended concentration and abamectin and fenpropathrin at both concentrations also reduced the production of capilliconidia significantly, although less than mentioned above.

\subsection{Effect of pesticides used in soybean on N. floridana sporulation and germination}

With the exception of two, all soybean fungicides tested resulted in a complete inhibition of $N$. floridana sporulation and germination (Table 3). The fungicide epoxiconazole did not result in a significant reduction in the production of primary conidia and capilliconidia compared with the control. Production of primary conidia in cadavers sprayed with cyproconazole was halved compared to the control. Among the three insecticides tested, lambda-cyhalothrin resulted in a significant inhibition of sporulation and germination at full concentrations, and deltamethrin resulted in a significant inhibition of germination at both concentrations.

\section{DISCUSSION}

Our results indicate that all fungicides tested reduced the sporulation and/or germination of the fungal pathogen N. floridana, while the acaricides/insecticides tested seemed to be less detrimental to this beneficial fungus. The effect of the different products on $N$. floridana varied considerably. Among all pesticides tested in this study, only cyprodinil + fludioxonil, lambda-cyhalothrin and 
Table 2. Effect of pesticides used in strawberry on the sporulation (production of primary conidia $\pm \mathrm{SE}$ ) and germination (production of capilliconidia $\pm \mathrm{SE}$ ) of $N$. floridana. Pesticides are applied at half the recommended concentration $(\mathrm{RC} / 2)$ and at the recommended concentration (RC)

\begin{tabular}{|c|c|c|c|c|}
\hline \multirow[b]{2}{*}{ Active ingredient (trade name) ${ }^{\mathrm{a}}$} & \multicolumn{2}{|c|}{ Mean umber of primary conidia per mummified mite $\pm \mathrm{SE}^{\mathrm{b}}$} & \multicolumn{2}{|c|}{$\begin{array}{l}\text { Percentage capilliconidial } \\
\text { formation } \pm S E^{b}\end{array}$} \\
\hline & $\mathrm{RC} / 2$ & $\mathrm{RC}$ & $\mathrm{RC} / 2$ & $\mathrm{RC}$ \\
\hline & \multicolumn{2}{|c|}{$F_{19,36}=7.05, P<0.01$} & \multicolumn{2}{|c|}{$F_{13,22}=18.61, P<0.01$} \\
\hline Control & $1834 \pm 125 a$ & $1834 \pm 125 a$ & $85 \pm 2 \mathrm{~A}$ & $85 \pm 2 \mathrm{~A}$ \\
\hline Abamectin (Vertimec $18 \mathrm{EC})^{\mathrm{A}}$ & $1283 \pm 169 \mathrm{abc}$ & $13 \pm 10 f$ & $38 \pm 12 \mathrm{BC}$ & $17 \pm 9 D$ \\
\hline Azoxystrobin $(\text { Amistar } 250 \mathrm{CS})^{\mathrm{F}}$ & $158 \pm 67$ ef & $350 \pm 135$ cdef & $2 \pm 1 \mathrm{D}$ & $7 \pm 4 D$ \\
\hline Cyprodinil + fludioxonil (Switch 62.5 WG $)^{\mathrm{F}}$ & 0 & 0 & 0 & 0 \\
\hline Fenpropathrin (Danimen $300 \mathrm{EC})^{\mathrm{A} / \mathrm{I}}$ & $1057 \pm 201 \mathrm{abcd}$ & $1129 \pm 298 \mathrm{abcd}$ & $36 \pm 2 C$ & $37 \pm 11 \mathrm{C}$ \\
\hline Fluazinam (Shirlan CS) ${ }^{\mathrm{F}}$ & $80 \pm 70 f$ & 0 & 0 & 0 \\
\hline Iprodione (Rovral 75 WG) ${ }^{\mathrm{F}}$ & $363 \pm 92$ bcdef & $124 \pm 41 \mathrm{f}$ & $2 \pm 0.1 \mathrm{D}$ & 0 \\
\hline Penconazole (Topas $100 \mathrm{EC})^{\mathrm{F}}$ & $413 \pm 121$ bcdef & $615 \pm 202$ abcdef & $10 \pm 4 D$ & $6 \pm 6 D$ \\
\hline Procymidone (Sumilex $500 \mathrm{WP}$ ) $\mathrm{F}$ & $163 \pm 78$ cdef & $116 \pm 75 f$ & $7 \pm 2 D$ & $4 \pm 4 D$ \\
\hline Propargite $(\text { Omite } 720 \mathrm{EC})^{\mathrm{A}}$ & $119 \pm 31 \mathrm{f}$ & $142 \pm 142$ ef & 0 & 0 \\
\hline Sulfur (Kumulus WG) ${ }^{\mathrm{F}}$ & 0 & 0 & 0 & 0 \\
\hline Sulfur (Thiovit Jet WG) ${ }^{F}$ & $162 \pm 84$ def & $177 \pm 103$ cdef & 0 & 0 \\
\hline Tebuconazole (Folicur $200 \mathrm{EC})^{\mathrm{F}}$ & $1051 \pm 186$ abcde & $1558 \pm 308 \mathrm{ab}$ & $65 \pm 1 A B$ & $37 \pm 11 \mathrm{C}$ \\
\hline
\end{tabular}

Table 3. Effect of two concentrations of pesticides used in soybean on the sporulation (production of primary conidia) and germination (production of capilliconidia) of $N$. floridana. Pesticides are applied at half the recommended concentration (RC/2) and at the recommended concentration (RC)

\begin{tabular}{|c|c|c|c|c|}
\hline \multirow[b]{2}{*}{ Active ingredient (trade name) ${ }^{\mathrm{a}}$} & \multicolumn{2}{|c|}{$\begin{array}{l}\text { Mean umber of primary } \\
\text { conidia per mummified mite } \pm S E^{b}\end{array}$} & \multicolumn{2}{|c|}{$\begin{array}{l}\text { Percentage capilliconidial } \\
\text { formation } \pm \mathrm{SE}^{\mathrm{b}}\end{array}$} \\
\hline & $\mathrm{RC} / 2$ & $\mathrm{RC}$ & $\mathrm{RC} / 2$ & $\mathrm{RC}$ \\
\hline & \multicolumn{2}{|c|}{$F_{10,47}=6.64, P<0.01$} & \multicolumn{2}{|c|}{$F_{8,39}=24.25, P<0.01$} \\
\hline Control & $1598 \pm 155 a$ & $1598 \pm 155 a$ & $73 \pm 3 \mathrm{~A}$ & $73 \pm 3 \mathrm{~A}$ \\
\hline Azoxystrobin (Priori $\mathrm{CS})^{\mathrm{F}}$ & 0 & 0 & 0 & 0 \\
\hline Azoxystrobin + cyproconazole (Priori Xtra CS)F & 0 & 0 & 0 & 0 \\
\hline Cyproconazole (Alto $100 \mathrm{CS})^{\mathrm{F}}$ & $609 \pm 52 b$ & $605 \pm 65 b$ & $32 \pm 3 B$ & $0.11 \pm 0.04 \mathrm{D}$ \\
\hline Deltamethrin (Decis $25 \mathrm{EC})^{\prime}$ & $1119 \pm 145 a b$ & $899 \pm 381 a b$ & $26 \pm 4 B C$ & $6 \pm 4 C$ \\
\hline Epoxiconazole (Opus CS) ${ }^{\mathrm{F}}$ & $821 \pm 126 a b$ & $787 \pm 159 a b$ & $60 \pm 12 \mathrm{~A}$ & $58 \pm 5 \mathrm{~A}$ \\
\hline Lambda-cyhalothrin (Karate Zeon 50 CS) ${ }^{1}$ & $985 \pm 337 \mathrm{ab}$ & $39 \pm 12 c$ & $83 \pm 5 \mathrm{~A}$ & 0 \\
\hline Permethrin (Talcord $250 \mathrm{EC})^{1}$ & $1242 \pm 213 a b$ & $1292 \pm 335 a b$ & $76 \pm 1 \mathrm{~A}$ & $74 \pm 4 \mathrm{~A}$ \\
\hline Pyraclostrobin + epoxiconazole (Opera EC) F & 0 & 0 & 0 & 0 \\
\hline Trifloxystrobin + tebuconazole (Nativo CS) ${ }^{\mathrm{F}}$ & 0 & 0 & 0 & 0 \\
\hline
\end{tabular}

propargite that were previously tested on N. floridana originated from T. evansi in Brazil ${ }^{26}$ and from T. urticae in Norway. ${ }^{10}$ However, in these studies, different methods of pesticide application were used. Cyprodinil + fludioxonil showed a complete inhibition of sporulation in our study, and in the studies by Klingen and Westrum $^{10}$ it reduced both the sporulation and the efficacy of the fungus against $T$. urticae (increased the median lethal time). Wekesa et al. ${ }^{26}$ studied the effect of lambda-cyhalothrin applied at a concentration of $0.4 \mathrm{~mL} \mathrm{~L}^{-1}$ and observed that capilliconidial formation was reduced by $16.8 \%$ compared with the control. In the present study, there was a total inhibition of capilliconidial formation when exposed to this insecticide. This may be due to the fact that we tested a different fungal strain in our experiment that was isolated from T. urticae, while Wekesa et al. ${ }^{26}$ isolated from T. evansi. Further, we used a higher concentration $\left(0.5 \mathrm{~mL} \mathrm{~L}^{-1}\right)$. The acaricide propargite did not inhibit sporulation, but it did affect the germination of primary conidia.

The negative effects of other fungicides on $N$. floridana had also been demonstrated by Boykin et al. ${ }^{17}$ using benzimidazole (Benomyl) and dithiocarbamate (Mancozeb). They demonstrated that 
these products reduced the incidence and efficiency of $\mathrm{N}$. floridana on T. urticae in peanut fields. Brandenburg and Kennedy ${ }^{24}$ also reported a lower incidence of $N$. floridana in T. urticae after application of the fungicides benzimidazole (Benomyl) and chlorothalonil (Termil) and attributed this effect to the inhibition of capilliconidial formation by these fungicides in cornfields. Klingen and Westrum ${ }^{10}$ conducted controlled laboratory studies on the killing capacity of $\mathrm{N}$. floridana to $\mathrm{T}$. urticae and reported that most of the fungicides they tested may potentially reduce the survival and efficacy of $N$. floridana, while some of the acaricide/insecticide/molluscicide products they tested seemed to have a stimulating effect on this beneficial fungus. The tests were conducted by letting N. floridana-infected T. urticae feed on strawberry leaves treated with different pesticides (three fungicides and one acaricide). Hence the effect of the pesticides was measured using an indirect method (through feeding/contact with the leaf by the mite) and not directly on the fungus itself, as in the present studies. The methodology in our study simulated a worst-case scenario and investigated the mode of action of pesticides in two parts of the life cycle of the fungus. The studies by Klingen and Westrum ${ }^{10}$ further showed that the fungicide tolylfluanid (Euparen M) and the acaricide methiocarb (Mesurol 500 CS) did not reduce the mortality of $N$. floridana-inoculated mites when compared with the control mites. However, tolylfluanid lowered the sporulation of the fungus to $15.5 \%$. Fenhexamid (Teldor 50 WG) also reduced the mortality of fungus-inoculated mites.

Studies conducted by Wekesa et $a l^{26}$ with pesticides used in tomatoes also showed that the fungicides [Orthocide (Captan) and Dithane (Mancozeb)] tested on N. floridana isolates from T. evansi (red tomato spider mite) resulted in a high reduction in sporulation and germination. The insecticide methomyl (Lannate) and the acaricide abamectin (Abamex) resulted in less pronounced effects on N. floridana. Two different methods were used in their studies: (1) fungus-killed mite cadavers were either immersed or sprayed with the pesticides; (2) the substrates used for sporulation (leaf discs and coverslips) were either immersed or sprayed with the pesticides.

If a pesticide is considered to be compatible with $\mathrm{N}$. floridana in laboratory bioassays (maximum exposure), we can assume that it will also be selective in the field. Further, we suggest that the acaricide abamectin and the insecticide lambda-cyhalothrin at half concentrations and the insecticides fenpropathrin and permethrin and the fungicide tebuconazole at the recommended concentrations may be the most suitable for use in $N$. floridana conservation biological control as part of an IPM programme because these pesticides resulted in the lowest impact on this beneficial fungus. In contrast, a pesticide resulting in negative effects on natural enemies in laboratory bioassays may not always necessarily result in negative effects in the field. This can be attributed to the fact that the entomopathogenic fungi may find refuge spaces within the crop, as pesticide applications in the field do not result in full coverage. Therefore, based on the present study, and considering that $N$. floridana is important in the natural population regulation of two-spotted spider mite, we suggest that farmers must apply with caution the pesticides sulfur, cyprodinil + fludioxonil, azoxystrobin, azoxystrobin + cyproconazole, trifloxystrobin + tebuconazole and pyraclostrobin + epoxiconazole until more comprehensive field studies are conducted. The sulfur-based fungicides Thiovit Jet WG and Kumulus WG were detrimental to $N$. floridana. Sulfur-based fungicides are extensively used by organic farmers, and there are few control alternatives against plant pathogenic fungi for organic farmers. The impact of sulfur on this beneficial fungus is reported for the first time here, and this information should be considered in IPM and organic cropping systems.

\section{ACKNOWLEDGEMENTS}

This research was funded by the Norwegian Foundation for Research Levy on Agricultural Products (FFL), the Agricultural Agreement Research Funds (JA) (through the project BERRYSYS, project number 190407/199), the Danish Agency for Science, Technology and Innovation and The São Paulo Research Foundation (through the project IMBICONT: 'Improved biological control for IPM in fruits and berries', project number 0603-00486B and 2011/51556-3 respectively). The first author is a recipient of a scholarship from the São Paulo Research Foundation (FAPESP, project number 2008/07358-0).

\section{REFERENCES}

1 Solomon MG, Jay CN, Innocenzi PJ, Fitzgerald JD, Crook D, Crook $\mathrm{AM}$ et al., Natural enemies and biocontrol of pests of strawberry in northern and central europe. Biocontrol Sci Technol 11(2):165-216 (2010).

2 Klubertanz TH, Pedigo LP and Carlson RE, Impact of fungal epizootics on the biology and management of the twospotted spider mite (Acari: Tetranychidae) in soybean. Environ Entomol 20(2):731-735 (1991).

3 Rezende J, Lofego A, Návia D and Roggia R, Mites (Acari: Mesostigmata, Sarcoptiformes and Trombidiformes) associated to soybean in Brazil, including new records from the cerrado areas. Fla Entomol 95(3):683-693 (2012)

4 Sances FV, Wyman JA and Ting IP, Physiological responses to spider mite infestation on strawberries. Environ Entomol 8(4):711 -714 (1979).

5 Bueno AF, Bueno RCOF, Nabity PD, Higley LG and Fernandes OA, Photosynthetic response of soybean to twospotted spider mite (Acari: Tetranychydae) injury. Braz Arch Biol Technol 52(4):825-834 (2009).

6 Gimenéz-Ferrer RM, Erb WA, Bishop BL and Scheerens JC, Host pest relationships between the twospotted spider mite (Acari: Tetranychidae) and strawberry cultivars with differing levels of resistance. JEcon Entomol 87(1):168-175 (1994).

7 Shanks $\mathrm{CH}$, Antonelli AL and Congdon BD, Effect of pesticides on twospotted spider mite (Acari: Tetranychidae) populations on red raspberries in western Washington. Agric Ecosyst Environ 38(3): $159-165$ (1992)

8 Hoyt SC, Westigard PH and Burts EC, Effects of two synthetic pyrethroids on codling moth (Lepidoptera: Olethreutidae), pear psylla (Hemiptera (Homoptera): Psyllidae) and various mite species in northwest apple and pear orchards. J Econ Entomol 71(3):431-434 (1978).

9 Bentley WJ, Zalom FG, Barnett WW and Sanderson JP, Population densities of Tetranychus spp. (Acari: Tetranychidae) after treatment with insecticides for Amyelois transitella (Lepidoptera: Pyralidae). J Econ Entomol 80(1):193-199 (1987).

10 Klingen I and Westrum K, The effect of pesticides used in strawberries on the phytophagous mite Tetranychus urticae (Acari: Tetranychidae) and its fungal natural enemy Neozygites floridana (Zygomycetes: Entomophthorales). Biol Control 43(2):222-230 (2007).

11 Roggia S, Guedes JVC, Kuss-Roggia RCR, Vasconcelos GJN, Navia D and Delalibera I, Jr, Predatory mites and the fungus Neozygites floridana associated with spider mites on soybean, in Rio Grande do Sul, Brazil. Pesqui Agropecu Bras 44(1):107-110 (2009).

12 Ribeiro AE, Gondim MG, Jr, Calderan E and Delalibera I, Jr, Host range of Neozygites floridana isolates (Zygomycetes: Entomophthorales) to spider mites. J Invertebr Pathol 102(3):196-202 (2009).

13 Keller S, The genus Neozygites (Zygomycetes, Entomophthorales) with special reference to species found in tropical regions. Sydowia 49(2):118-146 (1997).

14 Delalibera I and Hajek AE, Pathogenicity and specificity of Neozygites tanajoae and Neozygites floridana (Zygomycetes: Entomophthorales) isolates pathogenic to the cassava green mite. Biol Control 30(3):608-616 (2004). 
15 Van der Geest LP, Elliot SL, Breeuwer JA and Beerling EA, Diseases of mites. Exp Appl Acarol 24(7):497-560 (2000).

16 Delalibera I, Hajek AE and Humber RA, Use of cell culture media for cultivation of the mite pathogenic fungi Neozygites tanajoae and Neozygites floridana. J Invertebr Pathol 84(2):119-127 (2003).

17 Boykin LS, Campbell WV and Beute MK, Effect of pesticides on Neozygites floridana (Entomophthorales: Entomophthoraceae) and arthropod predators attacking the twospotted spider mite (Acari: Tetranychidae) in North-Carolina peanut fields. J Econ Entomol 77(4):969-975 (1984).

18 Carner GR and Canerday TD, Entomophthora sp. as a factor in regulation of twospotted spider mite in cotton. J Econ Entomol 63(2):638-640 (1970).

19 Nordengen I and Klingen I, Comparison of methods for estimating the prevalence of Neozygites floridana in Tetranychus urticae populations infesting strawberries. J Invertebr Pathol 92(1):1 -6 (2006).

20 Smitley DR, Kennedy GG and Brooks WM, Role of the entomogenous fungus, Neozygites floridana, in population declines of the twospotted spider mite, Tetranychus urticae, on field corn. Entomol Exp Applic 41(3):255-264 (1986).

21 Eilenberg J, Hajek A and Lomer C, Suggestions for unifying the terminology in biological control. BioControl 46(4):387-400 (2001).

22 Delalibera I, Jr, Demétrio CGB, Manly BFJ and Hajek AE, Effect of relative humidity and origin of isolates of Neozygites tanajoae (Zygomycetes: Entomophthorales) on production of conidia from cassava green mite, Mononychellus tanajoa (Acari: Tetranychidae), cadavers. Biol Control 39(3):489-496 (2006).

23 Brandenburg RL and Kennedy GG, Interactive effects of selected pesticides on the twospotted spider mite and its fungal pathogen Neozygites floridana. Entomol Exp Applic 34(3):240-244 (1983).

24 Brandenburg RL and Kennedy GG, Relationship of Neozygites floridana (Entomophthorales: Entomophthoraceae) to twospotted spider mite (Acari: Tetranychidae) population in field corn. J Econ Entomol 75(4):691-694 (1982).

25 Duarte VS, Silva RA, Wekesa VW, Rizzato FB, Dias CTS and Delalibera I, Jr, Impact of natural epizootics of the fungal pathogen Neozygites floridana (Zygomycetes: Entomophthorales) on population dynamics of Tetranychus evansi (Acari: Tetranychidae) in tomato and nightshade. Biol Control 51(1):81-90 (2009).
26 Wekesa VW, Knapp M and Delalibera I, Jr, Side-effects of pesticides on the life cycle of the mite pathogenic fungus Neozygites floridana. Exp Appl Acarol 46(1-4):287-297 (2008).

27 Jepsen SJ, Rosenheim JA and Matthews CE, The impact of sulfur on the reproductive success of Anagrus spp. parasitoids in the field. BioControl 52(5):599-612 (2007).

28 Beers EH, Martinez-Rocha L, Talley RR and Dunley JE, Lethal, sublethal, and behavioral effects of sulfur-containing products in bioassays of three species of orchard mites. J Econ Entomol 102(1):324-335 (2009).

29 Auger P, Guichou S and Kreiter S, Variations in acaricidal effect of wettable sulfur on Tetranychus urticae (Acari: Tetranychidae): effect of temperature, humidity and life stage. Pest Manag Sci 59(5):559-565 (2003).

30 Gent DH, James DG, Wright LC, Brooks DJ, Barbour JD, Dreves AJ et al., Effects of powdery mildew fungicide programs on twospotted spider mite (Acari: Tetranychidae), hop aphid (Hemiptera: Aphididae), and their natural enemies in hop yards. J Econ Entomol 102(1):274-286 (2009).

31 Way MJ and van Emden HF, Integrated pest management in practice - pathways towards successful application. Crop Prot 19(2):81-103 (2000).

32 Kogan M, Integrated pest management: historical perspectives and contemporary developments. Annu Rev Entomol 43(43):243-270 (1998).

33 Maredia KM, Integrated pest management in the global arena: Introduction and overview, in Integrated Pest Management in the Global Arena, ed. by Maredia KM, Mota-Sanchez D and Dakouo D. CABI Publishing, Cambridge, MA, p. 1 (2003).

34 McCullagh P and Nelder JA, Generalized Linear Models. Chapman and Hall, New York, NY/London, UK (1989).

35 Demétrio CGB, Hinde J and Moral RA, Models for overdispersed data in entomology, in Ecological Modelling Applied to Entomology, ed. by Ferreira CP and Godoy WAC. Springer International Publishing, Cham, Switzerland (2014).

36 R: A Language and Environment for Statistical Computing. [Online]. R Development Core Team, R Foundation for Statistical Computing, Vienna, Austria (2012). Available: http://www.R-project.org/ [2 March 2015]. 